\title{
Share Repurchases, Equity Issuances, and the Optimal Design of Executive Pay
}

\section{Citation}

Jesse M. Fried, Share Repurchases, Equity Issuances, and the Optimal Design of Executive Pay, 89 Texas Law Review 1113 (2011).

\section{Permanent link}

http://nrs.harvard.edu/urn-3:HUL.InstRepos:4905394

\section{Terms of Use}

This article was downloaded from Harvard University's DASH repository, and is made available under the terms and conditions applicable to Open Access Policy Articles, as set forth at http:// nrs.harvard.edu/urn-3:HUL.InstRepos:dash.current.terms-of-use\#OAP

\section{Share Your Story}

The Harvard community has made this article openly available.

Please share how this access benefits you. Submit a story.

\section{Accessibility}




\title{
Share Repurchases, Equity Issuances, and the Optimal Design of Executive Pay
}

\author{
Jesse M. Fried ${ }^{*}$
}

This Article identifies a cost to public investors of tying executive pay to the future value of a firm's stock-even its long-term value. In particular, such an arrangement can incentivize executives to engage in share repurchases (when the current stock price is low) and equity issuances (when the current stock price is high) that reduce "aggregate shareholder value": the amount of value flowing to all the firm's shareholders over time. The Article also puts forward a mechanism that ties executive pay to aggregate shareholder value and thereby eliminates the identified distortions.

\section{Introduction}

Public-company executives in the United States receive most of their pay in the form of equity compensation-restricted stock, stock options, and other incentives whose payoffs are tied to the future value of their firms' shares. ${ }^{1}$ Among S\&P 500 CEOs in 2009, on average more than $60 \%$ of compensation came in the form of restricted-stock and stock-option grants. ${ }^{2}$ Equity-based compensation is increasingly common in other countries as well. ${ }^{3}$

The purpose of equity compensation is to better align executives' interests with those of the firm's shareholders. ${ }^{4}$ Tying executives' payoffs more closely to the stock's future value should give executives stronger in-

* Professor of Law, Harvard Law School. For financial support, I am grateful to the John M. Olin Center for Law, Economics, and Business and the Harvard Law School Program on Corporate Governance. Elaine Choi, Daniel Doktori, Shawn Grover, Matt Hutchins, Audrey Lee, Da Lin, and Katherine Petti provided valuable research assistance. For helpful conversations and comments, I would like to thank Ken Ayotte, Joe Bachelder, Lucian Bebchuk, Bernie Black, Tom Brennan, Allen Ferrell, Victor Fleischer, Rob Jackson, Ira Kay, James Kim, Reinier Kraakman, Claudia Landeo, Kate Litvak, Mark Ramseyer, Guhan Subramanian, Fred Tung, participants at the 2010 ALEA Meeting, the Harvard Law and Economics Seminar, and the Northwestern Law and Economics Colloquium, and especially Louis Kaplow and Steve Shavell.

1. John E. Core et al., Executive Equity Compensation and Incentives: A Survey, FRBNY ECON. POL'Y REV., Apr. 2003, at 29.

2. See Equilar, 2010 CEO Pay Strategies: Compensation at S\&P 500 Companies 11 (2010).

3. See Brian R. Cheffins \& Randall S. Thomas, The Globalization (Americanization?) of Executive Pay, 1 BERKELEY BUS. L.J. 233, 246-47 (2004) (describing the increasing use of equitybased pay in Europe and Asia).

4. Michael C. Jensen \& Kevin J. Murphy, CEO Incentives-It's Not How Much You Pay, But How, Harv. Bus. Rev., May-June 1990, at 138, 139. 
centives to generate value for shareholders. ${ }^{5}$ Not surprisingly, the use of equity-based pay has long been encouraged by investors, regulators, and academics. $^{6}$

Most compensation arrangements tie executive pay to the short-term stock price. ${ }^{7}$ Unfortunately, a stock's short-term price does not necessarily reflect the stock's long-term value. Thus, over the last decade, there has been growing recognition that tying pay to the short-term stock price encourages executives to focus on short-term results at the expense of long-term value. $^{8}$ But recognition of the problems associated with tying pay to the short-term stock price has not diminished enthusiasm for the use of equity compensation itself; rather, it has led commentators to emphasize the importance of tying equity payoffs to the long-term stock price (which, the thinking goes, better reflects the stock's long-term value). ${ }^{9}$

This Article identifies a different and more subtle economic problem with equity pay - a problem that arises whenever an executive's payoff is tied to the future value of a firm's stock, even its long-term value. In particular, the Article shows that tying payoffs to the stock's future value fails to reward executives for maximizing what I have called "aggregate shareholder value": the amount of value flowing to all of the firm's shareholders over time. ${ }^{10}$ Indeed, I show that tying an executive's payoff to the stock's future value, even its long-term value, can encourage the

5. Id.

6. See, e.g., Jeffrey N. Gordon, "Say on Pay": Cautionary Notes on the U.K. Experience and the Case for Shareholder Opt-In, 46 HARV. J. ON LEGIS. 323, 352 (2009) (reporting that the widespread adoption of stock options in the 1990s resulted, in part, from institutional investor pressure on firms); Jensen \& Murphy, supra note 4, at 141 (urging boards to use more stock options to better tie equity pay to performance).

7. See lucian Bebchuk \& Jesse Fried, Pay Without Performance: The Unfulfilled PROMISE OF EXECUTIVE COMPENSATION 176-77 (2004) (describing executives' ability to unwind stock options and restricted shares as soon as they vest).

8. See, e.g., id. at 184 (analyzing problems resulting from the broad freedom of executives to unload equity incentives in the short term).

9. See, e.g., id. at 175 (suggesting that executives be required to hold stock for the long term); Lucian A. Bebchuk \& Jesse M. Fried, Paying for Long-Term Performance, 158 U. PA. L. REV. 1915, 1928-36 (2010) (putting forward more detailed recommendations for long-term holding requirements and explaining that executives should be allowed to unwind only a small fraction of their equity each year); Sanjai Bhagat \& Roberta Romano, Reforming Executive Compensation: Focusing and Committing to the Long-Term, 26 YALE J. ON REG. 359, 361 (2009) (suggesting that executives be paid only with restricted stock and stock options that cannot be unwound until after retirement).

10. See Jesse M. Fried, Informed Trading and False Signaling with Open Market Repurchases, 93 CALIF. L. REV. 1323, 1331 (2005). Aggregate shareholder value is the net cash flow from the firm to all of the firm's shareholders over time, where net cash flow equals the cash received by shareholders from the firm via dividends and share repurchases less any cash paid by shareholders to the firm for their shares. I use the term aggregate shareholder value rather than shareholder value because shareholder value may be taken to mean the value flowing to the firm's current shareholders. 
executive to take steps that destroy aggregate shareholder value (and therefore economic or "social" value ${ }^{11}$ ).

The Article describes and analyzes two distortions caused by tying an executive's payoff to a stock's future value. First, when the stock's current price is below its actual value, an executive whose pay is tied to the stock's future value can be rewarded for diverting cash from productive investments in the firm to fund bargain-price share repurchases. I call this distortionwhich involves socially excessive cash distributions by the firm- "costly contraction."

Second, when the stock's current price is higher than its actual value, the executive can be rewarded for issuing new shares even if the cash or other assets received for the newly issued shares cannot be used productively by the firm. I term this distortion-which involves socially excessive investment by the firm - "costly expansion." Both costly contraction and costly expansion can boost the stock's future value and executives' payouts even as they destroy aggregate shareholder value.

The reason why tying executive pay to the stock's future value leads to these two distortions is straightforward. Tying pay to the stock's future value aligns an executive's interests with the interests of only one group of shareholders, whom I call "nontrading shareholders": investors who neither sell any of their shares nor buy any additional shares until the executive receives the value of her shares. It fails to align the executive's interests with those of two other groups of shareholders: (1) "redeeming shareholders"investors who sell shares to the firm before the executive cashes out her equity, and (2) "investing shareholders"-investors who buy (additional) shares from the firm before the executive's cash-out date. Thus, tying an executive's pay to the stock's future value rewards the executive for transferring value to nontrading shareholders from redeeming shareholders (by buying the latter's shares at a low price) and from investing shareholders (by selling them shares at an inflated price), even if aggregate shareholder value - the amount of value flowing to all three groups of shareholders - is thereby diminished. ${ }^{12}$

11. For purposes of this Article, I assume that the firm's current and future shareholders are the only residual claimants to the firm's cash flow and thus that aggregate shareholder value is equivalent to social value. I will thus use the terms "aggregate shareholder value" and "social value" interchangeably. This assumption, made purely for expositional convenience, does not affect the Article's analysis of the distortions caused by tying executives' payoffs to the stock's future value, or the desirability of the constant-share proposal this Article puts forward.

12. Tying pay to the stock's future value also fails to tie executives' payoffs to the value flowing to two other groups of shareholders: (1) shareholders who sell their shares in the market before the executive's cash-out date and (2) the investors who buy these selling shareholders' stock. However, the cash that changes hands when investors buy and sell a firm's shares to each other in the secondary market does not affect aggregate shareholder value - the total amount of value flowing from the firm to shareholders over time. Rather, trading in the secondary market merely redistributes value among different shareholders. Thus, these shareholders' returns can be ignored 
I also put forward a mechanism that would perfectly tie executive pay to aggregate shareholder value: the "constant-share" approach to equity pay. Under this approach, an executive would be required to adjust her equity holdings in the firm whenever the firm purchases or sells its own shares to keep her percentage ownership constant through the transaction. Thus, the executive would be required to sell some of her shares whenever the firm repurchases its own stock and to buy additional shares when the firm issues new equity.

In essence, the constant-share approach requires the executive to participate equally as both a redeeming shareholder and as a nontrading shareholder when the firm repurchases shares, and as both an investing shareholder and a nontrading shareholder when the firm issues shares. The constant-share approach thus ties the executive's payoff to the value flowing to all of the firm's shareholders and rewards the executive for engaging in repurchases and equity issuances if and only if those transactions increase aggregate shareholder value. ${ }^{13}$

Before proceeding, I would like to be clear about the normative assumptions underlying this Article's analysis. Consistent with standard and widely used notions of efficiency that underlie most of the economically oriented scholarship on corporate governance, I assume that executivecompensation arrangements should reward executives for generating-not destroying - social value. ${ }^{14}$ Thus, as Michael Jensen has argued, executives should not be incentivized to redistribute value from future shareholders to current shareholders (or from one group of current shareholders to another) in ways that reduce social value, even if some of the firm's current shareholders are made better off. ${ }^{15}$

I would also like to indicate my objectives in this Article. Actual implementation of the constant-share approach at any given firm would require certain technical adjustments ${ }^{16}$ as well as the adoption of anticircumvention arrangements-issues that are beyond the scope of this

when analyzing the extent to which equity compensation ties executives' payoffs to aggregate shareholder value.

13. In this Article, I abstract from the question of how much-and what elements ofaggregate shareholder value should be paid to executives. That is, I do not consider here how much equity executives should receive, whether equity pay should take the form of stock or options, or the extent to which the payoffs from these instruments should be designed to filter out changes in the stock price that are due to market-wide or industry-wide fluctuations.

14. $C f$. William T. Allen et al., Commentaries and CASES ON the LaW of Business ORGANIZATION 7 (3d ed. 2009) (urging the use of Kaldor-Hicks efficiency as the criterion for evaluating corporate law and corporate governance arrangements).

15. See Michael C. Jensen, Agency Costs of Overvalued Equity, 34 Fin. Mgmt. 5, 16 (2005) (arguing that managers and the board should treat all shareholders-including future shareholdersequally to maximize the firm's long-run economic value).

16. For example, much of an executive's equity is likely to consist of vested stock options and unvested shares and stock options. Measuring the executive's proportional equity ownership would require assigning share-equivalents to these instruments. 
Article. I am thus not advocating adoption of any particular arrangement here. Rather, my goals in this Article are as follows: (1) to demonstrate that, just as there is a potential economic cost associated with tying executive pay to the short-term stock price, there is a potential economic cost associated with tying executive pay to the stock's future value-even its long-term value - when the company repurchases or issues shares; and (2) to show conceptually how compensation arrangements should be structured to tie executive pay to the value generated by a firm for its shareholders over time.

The remainder of the Article is organized as follows. Part II explains why equity pay can give executives an incentive to engage in excessive repurchases. It begins by showing that tying executive pay to the stock's future value rewards executives for engaging in repurchases when the stock's current price is below its actual value. It next explains how repurchases can reduce aggregate shareholder value by distributing cash that should be invested in the firm's own projects. It concludes by demonstrating that executives holding stock can be rewarded for conducting bargain-price repurchases even when those repurchases destroy social value.

Part III explains how equity pay gives executives an incentive to engage in excessive equity issuances. It begins by showing that tying executive pay to the stock's future value rewards executives for issuing equity when it is overpriced. It then demonstrates that the investments financed by such equity issuances can reduce social value. It concludes by showing that executives can be rewarded for inflated-price equity issuances even if the investments financed by these issuances destroy social value.

Part IV introduces the constant-share approach to equity pay, under which executives must maintain their proportional ownership as the firm transacts in its own stock. Such an approach, it shows, eliminates the incentive to engage in costly contraction and costly expansion created by tying executives' payoffs to the stock's future value. A conclusion follows.

\section{Equity Pay and Costly Contraction}

In this Part, I explain why tying executive payoffs to the stock's future value, even its long-term value, can reward executives for engaging in repurchases that reduce social value. Subpart A briefly discusses the growing use of repurchases as a means to distribute cash to shareholders. Subpart B shows that executives holding stock in the firm have a strong incentive to undertake repurchases when the firm's current stock price is below its actual value, and it summarizes the considerable evidence that executives frequently conduct such bargain-price repurchases. Subpart C explains how repurchases can reduce social value by diverting cash from valuable firm projects. Subpart D demonstrates that executives holding stock in the firm can be rewarded for engaging in such value-wasting repurchases when the current stock price is sufficiently low. 


\section{A. Widespread Use of Repurchases}

Publicly traded U.S. firms annually generate hundreds of billions of dollars in earnings. ${ }^{17}$ Each year, firms must decide how much of their retained earnings should be distributed to shareholders rather than left in the firm. Executives must also decide the form that such distribution should take: dividends, repurchases, or a combination of both. ${ }^{18}$

Share repurchases have become increasingly common and are now considered the dominant form of cash payout. ${ }^{19}$ Over $90 \%$ of U.S. public firms that distribute cash engage in repurchases. ${ }^{20}$ In 2007, S\&P 500 firms distributed almost $\$ 600$ billion through repurchases. ${ }^{21}$

A repurchase will typically take one of two forms: (1) an "open market repurchase" (OMR), in which the firm buys its own stock on the market through a broker, ${ }^{22}$ or (2) a "repurchase tender offer" (RTO), in which the firm offers to buy back its own stock directly from shareholders, usually at a premium over the market price. ${ }^{23}$ Because over $90 \%$ of repurchases take the form of OMRs, ${ }^{24}$ my analysis focuses primarily on OMRs. ${ }^{25}$

Economists believe that the growing use of repurchases rather than dividends is likely the result of the widespread use of stock options to com-

17. See Gustavo Grullon \& Roni Michaely, Dividends, Share Repurchases, and the Substitution Hypothesis, 57 J. FiN. 1649, 1655 tbl.1 (2002) (reporting annual aggregate earnings of U.S. firms from 1972 through 2000).

18. See generally Douglas J. Skinner, The Evolving Relation Between Earnings, Dividends, and Stock Repurchases, 87 J. Fin. ECON. 582 (2008) (comparing the percentages of firms that pay dividends, firms that repurchase shares, and firms that do both).

19. See id. at 584 .

20. See Gustavo Grullon \& David L. Ikenberry, What Do We Know About Stock Repurchases?, J. APPLIED CORP. Fin., Spring 2000, at 31,33-34 (reporting that in the 1990s additional cash flows were channeled into share repurchases instead of dividends); Skinner, supra note 20, at 583 (explaining that in 2005 only $7 \%$ of firms paid dividends and did not distribute any cash through repurchases).

21. Press Release, Standard \& Poor's, S\&P 500 Buybacks Set Record of $\$ 589$ Billion in 2007 (Apr. 7, 2008), available at http://www2.standardandpoors.com/spf/pdf/index/040708_SP500 BUYBACK_PR.pdf; see also Paul A. Griffin \& Ning Zhu, Accounting Rules? Stock Buybacks and Stock Options: Additional Evidence, 6 J. CONTEMP. ACCT. \& ECON. 1, 1 (2010) (reporting \$1 trillion of repurchases market wide in 2007).

22. Jesse M. Fried, Informed Trading and False Signaling with Open Market Repurchases, 93 CALIF. L. REV. 1323, 1335 (2005).

23. Jesse M. Fried, Insider Signaling and Insider Trading with Repurchase Tender Offers, 67 U. CHI. L. REV. 421, 421 (2000).

24. See Monica L. Banyi et al., Errors in Estimating Share Repurchases, 14 J. CORP. Fin. 460, 460 (2008) (reporting that since 1996 open market repurchase programs have accounted for $88 \%$ of all announced repurchase programs, and the announced value of these open market repurchases has been over $93 \%$ of the total reported value of repurchase programs); Grullon \& Ikenberry, supra note 22, at 33-34 \& fig.1 (reporting that between 1980 and 1999, open-market programs comprised about $92 \%$ of the total repurchase announcements and $91 \%$ of the total value of all repurchase announcements).

25. However, for purposes of this Article, the mechanism by which firms repurchase stock is irrelevant. 
pensate executives. ${ }^{26}$ Stock options provide a payoff equal to the difference between the (usually fixed) exercise price and the exercise-date stock price. ${ }^{27}$ A dividend reduces firm assets without affecting the number of shares. ${ }^{28} \mathrm{As}$ a result, a dividend reduces per-share value and the share price, thereby diminishing the value of an executive's stock options. ${ }^{29}$

A repurchase, in contrast, does not reduce per-share value (as much or at all) because it decreases firm assets and the number of shares outstanding by approximately the same proportion. ${ }^{30}$ Executives compensated with stock options are thus biased in favor of repurchases. ${ }^{31}$ Not surprisingly, executives with larger option packages tend to pay lower dividends and distribute more cash through share repurchases. ${ }^{32}$

However, as I explain below, even absent this stock-option bias, executives will often have an incentive to prefer repurchases over dividends. In particular, any executive whose payoff is tied to the stock's future value will get a larger payoff by engaging in a bargain-price repurchase than by issuing a dividend.

26. See, e.g., George W. Fenn \& Nellie Liang, Corporate Payout Policy and Managerial Stock Incentives, 60 J. FIN. ECON. 45, 48 (2001) (finding a statistically significant positive relationship between repurchases and management stock options, and concluding that management stock options help explain the rise in repurchases at the expense of dividends). Repurchases may also offer shareholders a number of possible advantages over dividends. In many cases, they are a more taxefficient mechanism than dividends for distributing cash. Repurchases (unlike dividends) also may enable firms to acquire shares for increasingly popular stock-option plans or provide liquidity to a firm's selling shareholders. See Fried, supra note 24, at 1336-40 (describing the possible advantages of repurchases over dividends and explaining why many of the advantages are likely to be quite modest).

27. See, e.g., Christine Jolls, Stock Repurchases and Incentive Compensation 1-2 (Nat'l Bureau of Econ. Research, Working Paper No. 6467, 1998), available at http://www.nber.org/ papers/w6467.pdf (describing the structure of stock options and exploring how this structure affects management incentives).

28. Id.

29. Id. One could preserve the value of an executive's stock option following a dividend by reducing the exercise price by the amount of the dividend. However, for various reasons such dividend adjustments are uncommon. See Kathleen M. Kahle, When a Buyback Isn't a Buyback: Open Market Repurchases and Employee Options, 63 J. Fin. ECON. 235, 242 n.2 (2002) ("“O]nly $1 \%$ of CEOs with options have dividend protection." (citation omitted)). Thus, dividends typically reduce the value of an executive's stock options. Jolls, supra note 29, at 2.

30. Jolls, supra note 31 , at 1.

31. Fenn \& Liang, supra note 30, at 65. Executives paid with restricted stock will also have an incentive to repurchase shares rather than issue dividends if the executives are not entitled to receive the value of any dividends paid while the restricted stock is vesting. However, most executives compensated with restricted stock appear to be entitled to receive dividends while the stock is still vesting. See Phyllis Plitch, Executives Find Restricted Stock Pays Dividends from the Get-Go, WALL ST. J., Feb. 28, 2005, at C3 (reporting an estimate that $90 \%$ of U.S. publicly traded companies award dividends on unvested restricted stock).

32. Fenn \& Liang, supra note 30 , at $47-48$. 


\section{B. Using Repurchases to Buy Low}

Executives whose payoff is tied to the future value of their firm's stock have a strong incentive to repurchase stock when the stock's current price is below its actual value. Indeed, there is substantial evidence that executives frequently engage in bargain-price repurchases. Even though firms are required to announce their intent to repurchase shares, underpricing can persist after such announcements are made.

1. Executives' Payoffs. - As I have shown elsewhere, ${ }^{33}$ a repurchase is economically equivalent to the following two-step transaction: First, redeeming (selling) shareholders sell their shares to nontrading (continuing) shareholders directly at the repurchase price. Second, the firm issues a dividend to nontrading shareholders equal to the dollar amount of the repurchase. Thus, a bargain-price repurchase transfers value from redeeming shareholders to continuing shareholders, including executives holding the firm's equity. ${ }^{34}$

A simple example can be used to illustrate how a bargain-price repurchase transfers value to executives holding equity in the firm. Consider $\mathrm{ABC}$ Corporation $(\mathrm{ABC})$ that has two shares outstanding and is liquidated at Liquidation Date. ${ }^{35}$ One share is held by its CEO. The other share is held by public shareholders. Consider two scenarios:

No-Transaction Scenario: Suppose that if ABC does not repurchase any of its equity prior to Liquidation Date, it will distribute $\$ 20$ to the holders of its two shares at Liquidation Date. The no-transaction value of each of ABC's two shares at Liquidation Date is thus $\$ 10$.

Repurchase Scenario: Now suppose that $\mathrm{ABC}$ can conduct a repurchase before Liquidation Date when the stock trades at $\$ 8$ ( $\$ 2$ less than its actual value of $\$ 10$ ), buying back public shareholders' single share at that price. Assume that the $\$ 8$ spent on the repurchase reduces ABC's Liquidation Date value from $\$ 20$ to $\$ 12$. At Liquidation Date, the value of $A B C$ 's remaining share (held by CEO) is thus $\$ 12$.

It should be easy to see that the bargain-price repurchase boosts CEO's payout without increasing social value - the value flowing to ABC's shareholders over time. In both the No-Transaction and Repurchase

33. Fried, supra note 10 , at $1344-46$.

34. When a firm buys stock at a price below its actual value, the precise distributional effects depend on whether the redeeming shareholders would have otherwise sold their shares to new investors for the same price. If so, the redeeming shareholder cannot be said to "lose" any value as a result of the bargain-price repurchase. Instead, the repurchase deprives would-be new investors of a gain. For simplicity, however, I will assume that it is the redeeming shareholders that lose money as the result of the bargain-price repurchase.

35. I assume that $\mathrm{ABC}$ does not issue any dividends (or sell any equity) before Liquidation Date. 
Scenarios, ABC's social value is $\$ 20 .^{36}$ But CEO's payout in the NoTransaction Scenario is only \$10, while in the Repurchase Scenario it is \$12. The results are summarized in Table 1 below.

Table 1. Rewards for Bargain-Price Repurchase

\begin{tabular}{|c|l|l|}
\hline & Social Value & CEO Payoff \\
\hline No Repurchase & $\$ 20$ & $\$ 10$ \\
\hline Repurchase & $\$ 20$ & $\$ 12$ \\
\hline
\end{tabular}

2. Evidence of Bargain Repurchases.-Having seen that executives holding equity have an incentive to conduct bargain repurchases, I now turn to the considerable empirical evidence that they do so. This evidence includes (a) executives' own statements and behavior, and (b) stock-price movements following repurchase announcements.

a. Executives' Own Statements and Behavior.-Executives admit that they frequently use repurchases to buy stock when it is cheap. According to the authors of a major 2005 survey of financial executives regarding their firms' payout policies, "[t]he most popular response for all repurchase questions on the entire survey is that firms repurchase when their stock is a good value, relative to its true value: $86.4 \%$ of all firms agree or strongly agree with this supposition." 37 The authors reported that "executives tell us that they accelerate (or initiate) share repurchases when their company's stock price is low. ${ }^{38}$

Empirical studies confirm that executives' desire to buy stock at a low price is linked to their equity ownership. One study found that abnormal returns following repurchase announcements, which are associated with prerepurchase underpricing, are positively correlated with pre-buyback executive stock ownership. ${ }^{39}$ Another found that relatively infrequent repurchase announcers - those firms that are more likely to be engaged in

36. In the No-Transaction Scenario, all \$20 flows to shareholders at Liquidation Date. In the Repurchase Scenario, \$8 flows to shareholders during the repurchase and \$12 flows to shareholders at Liquidation Date (for a total of \$20). Throughout the examples in this Article, I ignore the time value of money (or alternatively, assume it is zero). This assumption, made purely for convenience, does not affect the analysis.

37. Alon Brav et al., Payout Policy in the 21st Century, 77 J. FIN. ECON. 483, 514 (2005).

38. Id. Earlier studies yielded similar responses. When asked in a 1988 survey to name the most important circumstance precipitating a repurchase was, $66 \%$ of the surveyed executives responded "low stock price," six times as many as those offering the next most popular answer, "need for treasury stock." George P. Tsetsekos et al., A Survey of Stock Repurchase Motivations and Practices of Major U.S. Corporations, 7 J. Applied BuS. RES. 15, 17-18 tbl.2 (1991).

39. See Elias Raad \& H.K. Wu, Insider Trading Effects on Stock Returns Around Open-Market Stock Repurchase Announcements: An Empirical Study, 18 J. FIN. RES. 45, 57 (1995). 
bargain repurchasing than repurchasing shares to acquire stock for employeeoption programs - also tend to have higher levels of executive ownership. ${ }^{40}$ Both of these studies indicate that executives are more likely to engage in bargain-price repurchases when executives hold more equity.

Moreover, executives actively manipulate earnings to drive the stock price down around repurchases and thereby increase the amount of value transferred to themselves and other non-selling shareholders. ${ }^{41}$ Such earnings manipulation is more aggressive when the CEO's equity ownership is higher, providing additional evidence that executives conduct repurchases to boost the value of their equity. ${ }^{42}$

One might wonder why insider trading laws do not prevent executives from engaging in such indirect insider trading. But as I have explained elsewhere, ${ }^{43}$ there are substantial limits on the law's ability to deter corporations from using inside information to trade in their own stock. ${ }^{44}$ Executives are thus left with considerable ability to use the corporation for indirect insider trading when the stock price is below its actual value.

b. Post-announcement Stock Returns.-Stock-price movements following repurchase announcements also suggest that inside information drives many repurchases. If executives use repurchases to buy stock at a low price, the stock prices of firms announcing repurchases should, on average, subsequently outperform those of firms not announcing repurchases. Indeed, stock prices of firms announcing repurchases increase faster than stock prices of similar firms not announcing repurchases. One study found that shares of firms announcing repurchases earn abnormal returns of $6.7 \%$ in the first year following the announcement and $23.6 \%$ over the subsequent four years. ${ }^{45}$

Post-announcement returns are even higher in those firms that actually repurchase shares after making a repurchase announcement. ${ }^{46}$ Focusing on

40. See Murali Jagannathan \& Clifford Stephens, Motives for Multiple Open-Market Repurchase Programs, 32 Fin. MgMt. 71, 71-72 (2003).

41. See Guojin Gong, Henock Louis \& Amy X. Sun, Earnings Management and Firm Performance Following Open-Market Repurchases, 63 J. Fin. 947, 983 (2008) (reporting that firms adjust accruals to decrease their reported earnings before stock repurchases).

42. Id.

43. Fried, supra note 10 , at 1343.

44. Indeed, it is not completely clear under current law whether it is ever illegal for a corporation to buy its own stock in the public markets on inside information. See Mark J. Loewenstein \& William K.S. Wang, The Corporation as Insider Trader, 30 DEL. J. CORP. L. 45, 70-72 (2005) (noting that the SEC takes the position that an issuer trading on material inside information would violate Rule 10b-5 but that this position has not been endorsed by any court).

45. Konan Chan et al., Economic Sources of Gain in Stock Repurchases, 39 J. Fin. \& QuANT. ANALYSIS 461, 463 (2004); see also Urs Peyer \& Theo Vermaelen, The Nature and Persistence of Buyback Anomalies, 22 REV. Fin. STUD. 1693, 1701 (2009) (finding, in a large sample of firms announcing OMRs, a $24.25 \%$ cumulative market-adjusted return over 48 months following OMR announcements).

46. Chan et al., supra note 51, at 476. After making a repurchase announcement, which is not binding, executives can choose how much (if any) equity to actually repurchase. See Fried, supra 
"value firms" (firms with a high book-to-market ratio) that had announced repurchases, one study found that among the firms in which managers subsequently repurchased more than $4 \%$ of the firm's shares in the year following the repurchase announcement, four-year post-announcement abnormal returns were 57\%. For value firms that announced a repurchase but did not subsequently repurchase any shares, the authors of the study could not find any evidence of post-announcement abnormal returns. ${ }^{47}$ These post-announcement returns provide further strong evidence (along with executives' own statements and their behavior) that executives often use repurchases to indirectly buy underpriced stock.

\section{Why Bargain Pricing Persists After Repurchase Announcements.-} Because executives often use repurchases to buy stock at a low price, a repurchase announcement will tend to signal that the value of the stock is higher than the current market price. This signal, in turn, can be expected to boost the stock price, reducing the amount of underpricing and executives' ability to profit from a bargain-price repurchase. Indeed, if a repurchase announcement clearly signaled a certain amount of underpricing, the announcement should - in an efficient market - immediately eliminate the underpricing.

However, investors do not appear to immediately impart the information contained in repurchase announcements into the stock price, just as they do not immediately impart other types of information into the stock price. ${ }^{48}$ The failure of shareholders to immediately react to certain types of public information has been labeled by economists "investor underreaction." short, markets are not as efficient as some commentators might believe.

Moreover, even if markets were efficient at processing publicly available information, bargain pricing would still persist after repurchase announcements. A buyback announcement does not unambiguously signal that the stock is underpriced because boards may announce a buyback even

note 10, at 1335 (explaining that firms announcing authorization of open-market repurchases are not required to indicate the number of shares they intend to repurchase or to commit to repurchasing any shares).

47. See Konan Chan et al., Do Managers Time the Market? Evidence from Open-Market Share Repurchases, 31 J. BANKING FIN. 2673, 2676, 2686-88 (2007). For other studies indicating that executives in the United States and elsewhere tend to repurchase stock when it is underpriced, see Paul Brockman \& Dennis Y. Chung, Managerial Timing and Corporate Liquidity: Evidence from Actual Share Repurchases, 61 J. FIN. ECON. 417, 418 (2001), and Clifford P. Stephens \& Michael S. Weisbach, Actual Share Reacquisitions in Open-Market Repurchase Programs, $53 \mathrm{~J}$. FIN. 313, 313 (1998).

48. See David Ikenberry et al., Market Underreaction to Open Market Share Repurchases, $39 \mathrm{~J}$. FIN. ECON. 181, 183 (1995) (discussing delayed market reactions to announcements of important corporate events such as repurchases, mergers, proxy contests, and spinoffs).

49. See, e.g., Harrison Hong \& Jeremy C. Stein, A Unified Theory of Underreaction, Momentum Trading, and Overreaction in Asset Markets, 54 J. FIN. 2143, 2143 (1999); Ikenberry, supra note 53, at 183 . 
when the stock is not underpriced. For example, as I have explained elsewhere, executives might announce a repurchase program that they have no plan to actually conduct simply to boost the stock price so they can unload their own shares at a higher price. ${ }^{50}$ Indeed, a recent paper finds evidence of such "false signaling." T1 To the extent repurchase announcements are made for reasons other than conducting bargain repurchases, the resulting adjustment to the stock price will not completely eliminate any underpricing - even if the market is efficient. ${ }^{52}$

Because of the underreaction problem and the fact that some repurchase announcements are not driven by the desire to buy stock at a low price, the market response to repurchase announcements is, on average, rather muted. Repurchase announcements are associated with short-term abnormal price increases averaging $3 \%$ to $4 \%$ in the $1980 \mathrm{~s}^{53}$ and approximately $2 \%$ in the 1990s. ${ }^{54}$ The more muted the market's response to a repurchase announcement, the more profits executives can reap repurchasing underpriced stock.

\section{The Possibility of Costly Repurchases}

We have just seen that executives whose payoff is tied to the stock's future value have incentives to engage in bargain repurchases even if those repurchases do not increase social value. In addition, there is considerable evidence that executives do engage in bargain repurchases. ${ }^{55}$ I will now explain how repurchases (whether or not they are bargain priced) can reduce social value.

50. See Fried, supra note 10, at 1351-56 (developing the argument that executives can use repurchase announcements for false signaling and providing anecdotal accounts of such false signaling); Jesse M. Fried, Open Market Repurchases: Signaling or Managerial Opportunism?, 2 THEORETICAL INQUIRIES IN L. 865, 879-81 (2001) (explaining that executives can use repurchase announcements to boost the stock price before selling their shares). Alternatively, firms may announce a repurchase because they need to repurchase shares for employee stock-option programs.

51. See Konan Chan et al., Share Repurchases as a Potential Tool to Mislead Investors, $16 \mathrm{~J}$. CORP. FIN. 137, 139 (2010) (finding evidence consistent with the notion of executives of poorly performing firms making share repurchase announcements without an intention to repurchase shares).

52. Because of the problem of false signaling, I have suggested that firms be required to disclose not only their intention to repurchase shares but also the exact details of any buy orders given to brokers shortly before the orders are placed. Fried, supra note 10, at 1330. Such a predisclosure rule would increase the accuracy of price adjustments to repurchase announcements and reduce the amount of underpricing when the stock's price is below its actual value.

53. See Ikenberry et al., supra note 55, at 190 (reporting that the average market reaction to OMR announcements for all of the OMRs announced between January 1980 and December 1990 by firms listed on the ASE, NYSE, and NASDAQ was 3.54\%).

54. See Peyer \& Vermaelen, supra note 51, at 1697 (finding that, in a sample of OMR announcements from 1991-2001, there were average abnormal stock price reactions of $2.39 \%$ in the three days around the announcement).

55. See supra note 44 and accompanying text. 
1. How Repurchases Can Reduce Social Value.-A repurchase can reduce social value by distributing cash that, from a social perspective, could generate higher returns if invested in the firm's own projects. Suppose, for example, that $\$ 100$ left in the firm would generate a return of $15 \%(\$ 15)$. Suppose that if instead the $\$ 100$ were distributed to shareholders, the shareholders receiving the cash could generate returns of only $10 \%(\$ 10)$ outside the firm. Distributing the $\$ 100$ through a repurchase would thus destroy $\$ 5$ of social value.

In fact, there is evidence consistent with repurchases diverting cash that would otherwise be used in the firm. A recent study found that repurchases, especially those that appear to be driven by executive stock ownership, have a significantly negative effect on a firm's short-term investments and research and development. ${ }^{56}$ The study found that, everything else equal, doubling repurchases led to an $8 \%$ reduction in research-and-development expenditures. An earlier study came to similar conclusions - that repurchases led to firms diverting cash from potentially productive investments. $^{57}$

To be sure, these two studies do not establish that most repurchases destroy social value. But the studies do provide evidence that repurchases can divert cash from productive activities inside the firm, increasing the likelihood that some repurchases distribute cash that would generate more social value inside the firm.

2. Constraints on Firm Borrowing.-One might wonder why a firm that has a valuable project and whose stock trades at a low price cannot have its cake and eat it too. Indeed, in a world of perfect capital markets, there would be no need to sacrifice desirable firm projects to fund a bargain-price repurchase: firms could easily find the cash both to buy their stock at a low price and to invest in their high-value projects.

Consider the example above where shareholders can earn $10 \%$ on the cash they receive from the corporation and a $15 \%$ project is sacrificed to fund a \$100 repurchase. In a world of perfect capital markets, the corporation should be able to obtain financing for any project with a positive net present value $^{58}$ Thus, a firm's ability to invest in desirable projects would not depend on having cash on hand. A firm could both repurchase $\$ 100$ worth of

56. See Alok Bhargava, Executive Compensation, Share Repurchases, and Investment Expenditures: Econometric Evidence from U.S. Firms (2010) (unpublished manuscript) (on file with author).

57. See Daniel A. Bens et al., Real Investment Implications of Employee Stock Option Exercises, 40 J. ACCT. RES. 359, 359 (2002) (finding evidence that firms that repurchase shares to satisfy option exercises exhibit subsequent poor performance because the repurchases divert cash from productive investments).

58. Stewart C. Myers \& Nicholas S. Majluf, Corporate Financing and Investment Decisions when Firms Have Information that Investors Do Not Have, 13 J. FIN. ECON. 187, 187 (1984). 
shares and invest $\$ 100$ in the desirable project simply by borrowing another $\$ 100$ for the project.

However, there are a number of reasons why a firm may not borrow enough money to fully fund the desirable project. First, information asymmetry may prevent a firm from borrowing money on cost-effective terms. ${ }^{59}$ While the firm's executives may know that the firm's prospects are good, outside lenders asked to provide capital may lack sufficient information to reach the same conclusion. Outside lenders may thus demand terms that make the financing of the desirable project too costly, leading executives to forgo the project.

Second, even if a firm could borrow on reasonable terms from a lender, the borrowing may not be permitted by the firm's existing arrangements. For example, loan covenants with existing lenders might bar the firm from borrowing additional funds. Covenants are inevitably both underinclusive and overinclusive: they fail to prevent some value-decreasing activities and unfortunately prevent some value-increasing activities. ${ }^{60}$ In this case, a loan covenant preventing the firm from borrowing $\$ 100$ would be overinclusive: it would prevent the firm from financing a desirable project with additional debt. $^{61}$

Third, executives who are risk averse may wish to avoid the additional discipline imposed by more debt. Even if credit could be obtained on reasonable terms and the firm's existing arrangements would permit such a borrowing, the executives might personally be better off forgoing the valuable project rather than having the firm take on more debt. For any of these three reasons, there may be a trade-off between a firm's ability to repurchase its shares and its ability to fund productive activities inside the firm.

\section{Rewards for Costly Contraction}

We have seen that executives holding stock can profit from bargainprice repurchases and that repurchases can reduce social value. I will now show that executives whose payoff is tied to the stock's future value can be

59. See generally id. at $187-220$.

60. See Lucian Arye Bebchuk \& Jesse M. Fried, The Uneasy Case for the Priority of Secured Claims in Bankruptcy, 105 YALE L.J. 857, 879 (1996) (noting that the difficulty of specifying all possible contingencies is likely to cause covenants to be overinclusive in some respects); Marcel Kahan \& David Yermack, Investment Opportunities and the Design of Debt Securities, 14 J.L. ECON. \& ORG. 136, 138-40 (1998) (explaining that the potential overinclusiveness of particular covenants may cause the parties to avoid such covenants when their ability to renegotiate these covenants is diminished).

61. In principle, these covenants preventing a value-increasing investment could be renegotiated, with the resulting surplus shared between the lender and the borrower. But such renegotiation is often difficult or costly, particularly when the borrower must simultaneously renegotiate with multiple creditors to obtain the modifications needed to facilitate the new investment. 
rewarded for engaging in value-wasting repurchases. I will then explain that other components of executives' pay packages fail to mitigate this distortion.

1. Equity Pay and Costly Repurchases.-To see why executives holding the firm's equity can be rewarded for costly contraction, let us return to the example of $\mathrm{ABC}$ Corporation introduced in subpart B. As before, $\mathrm{ABC}$ has two shares outstanding and is liquidated at Liquidation Date. ${ }^{62}$ One share is held by its CEO. The other share is held by public shareholders. Consider two scenarios:

No-Transaction Scenario: Suppose that if ABC does not repurchase any of its equity prior to Liquidation Date, it will distribute $\$ 20$ to the holders of its two shares at Liquidation Date. The no-transaction value of each of ABC's two shares at Liquidation Date is thus $\$ 10$.

Costly Repurchase Scenario: Now suppose that ABC can conduct a repurchase before Liquidation Date when the stock trades at \$8 (\$2 less than its actual value of \$10), buying back public shareholders' single share at that price. Assume that the $\$ 8$ spent on the repurchase reduces $A B C$ 's Liquidation Date value by $\$ 9$, from $\$ 20$ to $\$ 11$, because $A B C$ must give up a valuable project. At Liquidation Date, the value of $\mathrm{ABC}$ 's remaining share (held by CEO) is thus $\$ 11$.

It should be easy to see that the costly bargain-price repurchase boosts CEO's payout even though it reduces social value. In the No-Transaction Scenario, ABC's social value is $\$ 20$; in the Costly Repurchase Scenario, $\mathrm{ABC}$ 's social value is $\$ 19 .^{63}$ But CEO's payout in the Costly Repurchase Scenario is $\$ 11, \$ 1$ more than in the No-Transaction Scenario. The effect of the repurchase on social value and CEO's payoff can be summarized in the following table:

Table 2. Rewards for Costly Repurchase

\begin{tabular}{|c|l|l|}
\hline & Social Value & CEO Payoff \\
\hline No Repurchase & $\$ 20$ & $\$ 10$ \\
\hline Repurchase & $\$ 19$ & $\$ 11$ \\
\hline
\end{tabular}

As one can see, an executive whose payoff is tied to the stock's future value can be rewarded for repurchasing shares even when the transaction destroys social value. The problem is that tying the executive's payoff to the stock's future value aligns the executive's interests with those of nontrading

\footnotetext{
Date.

62. I assume that $\mathrm{ABC}$ does not issue any dividends (or sell any equity) before Liquidation

63. In the No-Transaction Scenario, all \$20 flows to shareholders at Liquidation Date. In the Repurchase Scenario, \$8 flows to shareholders during the repurchase and $\$ 11$ flows to shareholders at Liquidation Date (for a total of \$19).
} 
shareholders but not with those of redeeming shareholders. Thus, the executive has an incentive to transfer value from redeeming shareholders to nontrading shareholders even when such transfer destroys social value. Importantly, this distortion arises even if the executive's payoff is tied to the stock's long-term value.

2. Do Other Pay Components Mitigate?-We just saw that an executive whose payoff is tied to the stock's future value can be rewarded for engaging in a repurchase that reduces social value. But executives are typically free to sell much of their equity in the short term. ${ }^{64}$ One might think that having stock that could be sold in the short term would (at least partially) tie the executive's payoff to that of short-term shareholders, including redeeming shareholders who sell stock back to the corporation when the firm conducts a repurchase.

However, the fact that executives can sell stock in the short term does not mean that they will sell stock in the short term. When executives know that the stock is underpriced and conduct a repurchase in order to indirectly buy stock at a low price, they can be expected to hold onto their personal shares until the stock price rises. In fact, there is evidence that executives buy additional shares for their personal accounts before and during bargain repurchases. ${ }^{65}$ Thus, other components of executives' compensation arrangements will not mitigate their incentive to engage in bargain-price repurchases that destroy value. ${ }^{66}$

\section{Equity Pay and Costly Expansion}

Part II demonstrated that an executive whose payoff is tied to the stock's future value can be rewarded for inefficiently contracting the firm's operations when the firm's current stock price is below its actual value. This Part shows that such an executive can also be rewarded for inefficiently expanding the firm's operations when the firm's current stock price is above its actual value. In particular, such an executive benefits from having the firm sell additional equity at inflated prices, even when the assets acquired by the firm in such an issuance are invested in ways that reduce social value.

Subpart A discusses the widespread use of equity issuances by firms. Subpart B explains that an executives whose payoff is tied to the stock's future value benefit when the firms sell overpriced stock. It also provides evidence that such inflated-price issuances are common. Subpart $C$ explains why equity issuances can reduce social value. Subpart D then shows that

64. See BEBCHUK \& FRIED, supra note 7, at 174-79.

65. See Raad \& Wu, supra note 45 , at 57 (reporting higher levels of insider stock purchases in the month immediately preceding a share repurchase announcement).

66. Of course, executives whose total pay is tied to firm size may have somewhat less incentive to engage in a costly repurchase, or indeed any kind of repurchase. 
such an executive can benefit even if inflated-price issuances lead to a reduction in social value.

\section{A. The Use of Share /ssuances}

After undergoing an IPO, a publicly traded firm usually continues to issue shares throughout its life. ${ }^{67}$ Such issuances typically serve one of three purposes. First, stock is issued to employees as part of their compensation packages. ${ }^{68}$ Second, stock issuances are used to raise cash for operations and strategic investments or to pay down debt. ${ }^{69}$ Third, in the context of corporate acquisitions, stock is often issued to target shareholders as consideration for their shares in the target company. ${ }^{70}$

Although equity issuances have different purposes, all have the same economic consequence: they directly or indirectly move cash or other assets into the firm. ${ }^{71}$ Equity issuances thus have the opposite effect of repurchases. While repurchases remove value from the firm and put it into the hands of shareholders, equity issuances take value from shareholders and put it into the firm's hands.

\section{B. Using Share /ssuances to Sell High}

This subpart explains that an executive whose payoff is tied to the stock's future value has a strong incentive to issue shares when the stock's current price is higher than its actual value. It then describes the substantial evidence that executives frequently engage in inflated-price issuances.

1. Executives' Payoffs.-An equity issuance has analogous distributional effects to a share repurchase. As we saw in Part II, a share repurchase transfers value from redeeming shareholders to nontrading shareholders when the stock price is below the stock's actual value.

67. See Eugene F. Fama \& Kenneth R. French, Financing Decisions: Who Issues Stock?, 76 J. FIN. ECON. 549, 550 (2005) (reporting that $86 \%$ of publicly traded firms in their sample issued stock after their IPOs between 1993 and 2002).

68. Among the largest 200 firms in 2007, the range of shares allocated to equity compensation plans ranged from $0.92 \%$ of outstanding shares to $62.6 \%$ of outstanding shares, with the median

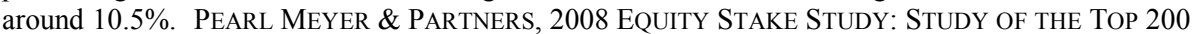
CORPORATIONS 2 (2009).

69. See Fama \& French, supra note 74, at 573-74 (describing various purposes for stock issuances). These cash-raising issuances may take the form of seasoned equity offerings, private placements, convertible debt, warrants, or rights issues. Id. at 550.

70. See id. at 554 (explaining the tax advantage of using acquirer-firm stock to purchase shares of targets).

71. The issuance of equity for compensation indirectly moves cash into the firm. The firm gives equity to executives and other employees, who eventually sell the equity for cash on the open market to investors. This practice has the same economic effect as a transaction in which the investors buy stock from the firm for cash and the firm then uses the cash to compensate executives and other employees. The issuance of stock to raise cash to pay down debt can also indirectly shift cash into the firm by reducing future interest payments. 
Similarly, a stock issuance transfers value from investing shareholders to nontrading shareholders when the stock's price is above its actual value.

Like a share repurchase, an equity issuance is economically equivalent to a two-part transaction that involves investing shareholders trading directly with nontrading shareholders. In particular, a stock issuance is economically equivalent to (1) the firm issuing shares pro rata to nontrading and investing shareholders for the issuance price, and (2) nontrading shareholders selling their portion of the issued shares to the investing shareholders for the issuance price. Thus, an equity issuance transfers value from investing shareholders to nontrading shareholders (including executives holding stock) when the sale price exceeds the value of the issued stock.

To illustrate the incentive of executives holding stock to conduct inflated-price offerings, consider again $\mathrm{ABC}$ Corporation. As before, it has two shares outstanding, one held by CEO and one held by public shareholders, and it is liquidated at Liquidation Date. ${ }^{72}$ Consider two scenarios:

No-Transaction Scenario: Suppose that if ABC does not sell any of its equity prior to Liquidation Date, it will distribute $\$ 20$ to the holders of its two shares at Liquidation Date. The no-transaction value of each of ABC's two shares at Liquidation Date is thus $\$ 10$.

Equity /ssuance Scenario: Now suppose that $\mathrm{ABC}$ can conduct an equity issuance before Liquidation Date when the stock trades at $\$ 13$ (\$3 more than its actual value of $\$ 10$ ), selling a third share at that price. Assume that the $\$ 13$ received by $\mathrm{ABC}$ increases $\mathrm{ABC}$ 's Liquidation Date value from $\$ 20$ to $\$ 33$. At Liquidation Date, the value of each of $A B C$ 's three shares (including that held by CEO) is thus $\$ 11$.

It should be easy to see that the inflated-price issuance boosts CEO's payout without increasing social value - the value flowing to $A B C$ 's shareholders over time. In both the No-Transaction Scenario and Equity Issuance Scenario, $\mathrm{ABC}$ 's social value is $\$ 20 .^{73}$ But CEO's payout in the No-Transaction Scenario is only $\$ 10$, while in the Equity Issuance Scenario it is $\$ 11$. The results are summarized in Table 3 below.

Table 3. Rewards for Inflated-Price Issuance

\begin{tabular}{|l|l|l|}
\hline & Social Value & CEO Payoff \\
\hline No Equity Issuance & $\$ 20$ & $\$ 10$ \\
\hline Equity Issuance & $\$ 20$ & $\$ 11$ \\
\hline
\end{tabular}

72. I assume that $\mathrm{ABC}$ does not issue any dividends (or repurchase any equity) before Liquidation Date.

73. In the No-Transaction Scenario, all $\$ 20$ flows to shareholders at Liquidation Date. In the Equity Issuance Scenario, $\$ 13$ flows from shareholders during the equity issuance, and $\$ 33$ flows back to shareholders at Liquidation Date (for a net amount of \$20). 
2. Evidence of Inflated-Price /ssuances.-There is considerable evidence that firms tend to conduct seasoned equity offerings (SEOs) transactions in which cash is raised from new and existing shareholderswhen the stock is overpriced. ${ }^{74}$ For example, one well-known study found that firms undertaking SEOs systematically underperform benchmark stocks over the five-year post-offering period. ${ }^{75}$ This pattern of underperformance indicates that the shares sold were, on average, overpriced at the time of the SEO. ${ }^{76}$

When a firm's shares are overpriced, the firm is also more likely to acquire other companies and use its shares as consideration in the merger. ${ }^{77}$ There is evidence that such acquisitions boost the long-term stock value of the acquiring firms' shares by enabling the acquiring firms to purchase assets cheaply. ${ }^{78}$ To the extent executives of these firms hold equity that they

74. See, e.g., Tim Loughran \& Jay R. Ritter, The New /ssues Puzzle, 50 J. Fin. 23, 25, 47 (1995) (examining 3702 seasoned equity offerings between 1970 and 1980 and finding evidence consistent with firms announcing stock issues when the stock is grossly overvalued, the market failing to revalue the stock appropriately, and the stock remaining overvalued when the issue occurs).

75. See Loughran \& Ritter, supra note 74, at 23-25 (examining SEO underperformance between 1970 and 1990); see a/so Jeffrey Pontiff \& Artemiza Woodgate, Share /ssuance and Cross-sectional Returns, 63 J. FIN. 921, 943-44 (2008) (finding evidence of post-SEO stock underperformance in a more recent sample of U.S. SEOs). For evidence that SEOs are used in other countries to sell stock at an inflated price, see Brian J. Henderson et al., World Markets for Raising New Capital, 82 J. FIN. ECON. 63, 66 (2006) (concluding that "firms are more likely to issue equity when the stock market appears to be overvalued").

76. The failure of investors to immediately impart all of the information signaled by these transactions into the stock price is another example of the investor underreaction discussed earlier. See, e.g., Loughran \& Ritter, supra note 74, at 47-48 (discussing the market's "misvaluation" of SEOs).

77. See, e.g., Ming Dong et al., Does Investor Misvaluation Drive the Takeover Market?, $61 \mathrm{~J}$. FIN. 725, 757 (2006) (finding that overpriced firms are more likely to try to acquire other firms that are less overpriced); Matthew Rhodes-Kropf et al., Valuation Waves and Merger Activity: The Empirical Evidence, 77 J. FIN. ECON. 561, 600-01 (2005) (concluding that the "vast majority" of mergers involve "highly overvalued bidders"); Itzhak Ben-David et al., Are Stock Acquirers Overvalued? Evidence from Short Selling Activity 23-24 (Fisher Coll. of Bus. Working Paper Series, Working Paper No. 2010-03-011, 2010), available at http://www.ssrn.com/abstract= 1572686 (determining that short-selling activity is consistent with acquirers using overvalued stock to buy other companies); cf. Matthew Rhodes-Kropf \& S. Viswanathan, Market Valuation and Merger Waves, 59 J. Fin. 2685, 2710 (2004) (presenting a model in which acquirers are more likely to use stock when they are overvalued); Andrei Shleifer \& Robert W. Vishny, Stock Market Driven Acquisitions, 70 J. FIN. ECON. 295, 300 (2003) (proposing that overvalued firms engage in stockfinanced acquisitions so that the overvalued firms' shareholders can benefit from obtaining hard assets at a discount).

78. See Pavel G. Savor \& Qi Lu, Do Stock Mergers Create Value for Acquirers?, 64 J. FIN. 1061, 1063 (2009) (finding that the shares of a sample of stock-financed bidders that completed their acquisitions outperformed a control sample of stock-financed bidders that failed to complete their acquisitions by $25-30 \%$ over a three-year horizon, and demonstrating that the outperformance was due to the successful bidders ability to acquire cheap assets); cf. Tim Loughran \& Anand M. Vijh, Do Long-Term Shareholders Benefit from Corporate Acquisitions?, 52 J. FIN. 1765, 1775 (1997) (finding that managers of acquiring firms use stock to pay for the acquisitions when their firms' stock is likely to be overvalued and cash when their firms' stock is likely to be undervalued). 
cannot currently cash out, they will benefit from using overpriced stock to acquire target assets at a discount. ${ }^{79}$

Recall from Part II that there is evidence that executives manipulate the stock price down around stock buybacks to increase their profits from bargain-price repurchases. Similarly, executives manipulate the stock price up around equity offerings in order to increase the amount transferred from investors buying stock from the firm. One study found that seasoned equity issuers are more likely to manipulate earnings than nonissuers and that such manipulations boost the price around the equity offering. ${ }^{80}$ Such earnings manipulations also occur when the stock is being used to acquire another company. ${ }^{81}$

\section{The Possibility of Costly Expansion}

As we have seen, an executive whose payoff is tied to the stock's future value are rewarded for conducting inflated-price issuances, and there is considerable evidence that such issuances are common. This subpart shows that equity issuances can reduce social value by diverting money or other assets into firm investments that yield lower returns than investments outside of the firm.

1. Why Expansion Can Reduce Social Value.-Just as a share repurchase can reduce social value by distributing cash that should be invested in the firm's own projects, an equity issuance can reduce social value by enabling the firm to engage in projects that yield a lower return than projects outside of the firm. Suppose, for example, that the $\$ 100$ raised by an equity issuance would generate a return of $10 \%$ outside of the firm. Suppose

79. To the extent the stock is overpriced and insiders can cash out some of their equity immediately, they will have an incentive to unwind this equity even as they seek to boost the value of their remaining shares by having the firm issue overpriced stock. See Daniel Bradley et al., Do Insiders Practice What They Preach? Informed Option Exercises Around Acquisitions 4-5 (Feb. 2009) (unpublished manuscript), available at http://papers.ssrn.com/sol3/papers.cfm?abstract id= 1364787 (finding that, around the announcement of stock-financed acquisitions, insiders of the acquiring firm exercise stock options and sell the underlying shares).

80. See Siew Hong Teoh et al., Earnings Management and the Underperformance of Seasoned Equity Offerings, 50 J. FIN. ECON. 63, 64-65 (1998) (reporting that seasoned equity issuers raise reported earnings by altering discretionary accruals and that this manipulation lowers post-offering returns); cf. Daniel A. Cohen \& Paul Zarowin, Accrual-Based and Real Earnings Management Activities Around Seasoned Equity Offerings 4, 10 (June 2008) (unpublished manuscript), available at http://ssrn.com/abstract=108193 (finding use of both accrual-based and real earnings management in a sample of 1,511 SEOs between 1987 and 2006).

81. See, e.g., Merle Erickson \& Shiing-wu Wang, Earnings Management by Acquiring Firms in Stock for Stock Mergers, 27 J. ACCT. \& ECON. 149, 151 (1999) (finding, in a sample of stockfinanced mergers between 1985 and 1990, that acquirers managed earnings upward before announcing the merger); Henock Louis, Earnings Management and the Market Performance of Acquiring Firms, 74 J. FIN. ECON. 121, 134, 136 tbl.4 (2004) (finding that acquiring firms overstate earnings prior to stock-for-stock acquisitions). 
further that, if invested in the firm, the $\$ 100$ would generate returns of $5 \%$. The $\$ 100$ equity issuance would thus destroy $\$ 5$ of social value.

Substantial evidence suggests that expansions facilitated by equity issuances can reduce social value. For example, acquisitions - many of which are financed by the acquirer issuing stock-frequently reduce the aggregate wealth of both acquirer and target shareholders. ${ }^{82}$ One study found that during the period from 1998 to 2001, the combined value of acquirer and target stock fell over $\$ 100$ billion following acquisition announcements. ${ }^{83}$

It is well-known that much of this value destruction occurs when firms have overpriced stock to pay for their acquisitions. ${ }^{84}$ One oft-cited example of a value-destroying acquisition financed by overpriced equity is America Online's (AOL) acquisition of Time Warner in $2000 .{ }^{85}$ AOL, with a market capitalization of over $\$ 200$ billion, used $\$ 162$ billion of its own stock to acquire Time Warner. ${ }^{86}$ Whatever or not AOL's executives expected the merger to generate synergy benefits, it failed to do so. Because the companies were worth more separated than together, AOL and Time Warner parted ways nine years later. ${ }^{87}$ When AOL was spun off, it was worth $\$ 3.5$ billion while Time Warner was valued at about $\$ 36$ billion. ${ }^{88}$

Although the merger was a bust, AOL's original shareholders could have benefitted substantially from the transaction. Had AOL not acquired Time Warner, AOL shareholders would have seen the value of their shares decline from approximately $\$ 200$ billion to several billion dollars over the next decade. Instead, AOL shareholders ended up owning a large fraction of Time Warner, which ten years later had a market capitalization more than ten times that of AOL. Thus, acquisitions using high-priced stock can boost the

82. See Sara B. Moeller et al., Wealth Destruction on a Massive Scale? A Study of AcquiringFirm Returns in the Recent Merger Wave, 60 J. FIN. 757, 759 (2005) (finding that decreases in acquirer shareholder value were not due to wealth transfers from acquiring shareholders to target shareholders because the combined value of the acquirer and the target decreased significantly).

83. Id. To the extent that some of the decrease in the acquirer stock price following acquisition announcements is due to the offer signaling that the acquirer is overpriced, not all of this loss in shareholder value necessarily represents a destruction of social value.

84. See Michael C. Jensen, Agency Costs of Overvalued Equity, 34 Fin. Mgmt. 5, 10 (2005) (arguing that managers of firms with overpriced stock make poor acquisitions in part to buy assets cheaply).

85. See Tim Arango, How the AOL-Time Warner Merger Went So Wrong, N.Y. TIMES, Jan. 11, 2010, http://www.nytimes.com/2010/01/11/business/media/11merger.html?_r=1 (reporting that the 2000 deal valued the combined firm at $\$ 350$ billion and that ten years later the combined values of the companies, which have since been separated, was about one-seventh of their combined values on the day of the merger).

86. See Daniel Okrent, Happily Ever After?, Time, Jan. 24, 2000, at 39, 39 (reporting that the transaction was an all-stock acquisition for about $\$ 162$ billion of AOL stock).

87. See W. David Garnder, AOL Completes Spin-Off From Time Warner, InFormation WeEK (Dec. 10, 2009), http://www.informationweek.com/news/internet/ebusiness/showArticle.jhtml? articleID $=222001597$.

88. Id. 
long-term value of the acquiring firm's shares even if the acquisitions end up destroying social value.

\section{Why Not Sell Overpriced Shares and Distribute the Cash to} Shareholders? - A firm that sells inflated-price equity could, in principle, simply distribute the sale proceeds to its shareholders rather than invest the proceeds in unproductive activities. Indeed, the firm's current shareholders and its executives would be much better off if the cash raised by an inflatedprice offering could be used to generate high returns outside of the firm rather than low returns inside the firm.

Why then would executives ever use the cash raised from an inflatedprice offering to make unproductive investments in the firm? The reason is simple: a firm selling equity must inform its old and new investors of the purpose of the financing. ${ }^{89}$ If the firm announces that it will take all of the funds raised and hold them in cash or distribute them to shareholders, investors are likely to infer that the firm is issuing stock merely to exploit the overpricing of its stock. ${ }^{90}$ Investors may thus refuse to purchase shares, preventing the firm from selling overpriced equity.

Because firms selling equity cannot simply distribute the cash to investors, firms generally must use the funds for some other purpose, such as increasing investment. ${ }^{91}$ Thus, if the firm has poor investment opportunities, the only way to sell overpriced stock may be to use the proceeds for valuewasting investments. Unfortunately, as we will see shortly, executives holding stock in their firms can be rewarded for such value-wasting investments.

\section{Rewards for Costly Expansion}

Having seen that equity issuances can reduce social value, we will now see that an executive whose payoff is tied to the stock's future value can be rewarded by engaging in inflated-price equity issuances that reduce social value. I will then explain that other components of executives' pay packages do not mitigate this distortion.

89. See, e.g., SEC, Registration Statement Under the Securities Act of 1933, at 10 (Form S-3), available at www.sec.gov/about/forms/forms-3.pdf (requiring a stock issuer to furnish the information required by Item 504 of Regulation S-K, namely the "principal purposes for the which the proceeds are to be used").

90. See, e.g., Merritt B. Fox, Civil Liability and Mandatory Disclosure, 109 CoLuM. L. REv. 237, $262 \&$ n.65 (2009) (observing that the distribution of proceeds from a new equity sale would signal that the issuer sold the shares simply because it believed the stock was overpriced).

91. See Woojin Kim \& Michael S. Weisbach, Motivations for Public Equity Offers: An International Perspective, 87 J. FIN. ECON. 281, 283 (2008) (reporting that equity offerings are done both to raise investment capital and to exploit favorable market conditions); Ming Dong et al., Stock Market Misvaluation and Corporate Investment 4 (Munich Personal RePEc Archive, Paper No. 3109, 2007), available at http://mpra.ub.uni-muenchen.de/3109 (finding that cash raised by overpriced firms issuing equity is used to increase investment). 
1. Equity Pay and Costly Expansion.-Executives whose payoffs are tied to the stock's future value can be rewarded for engaging in inflated-price equity issuances, even if those issuances reduce social value.

Return again to $\mathrm{ABC}$ Corporation. As before, it has two shares outstanding, one held by CEO and one held by public shareholders, and is liquidated at Liquidation Date. ${ }^{92}$ Consider two scenarios:

No-Transaction Scenario: Suppose that if ABC does not sell any of its equity prior to Liquidation Date, it will distribute $\$ 20$ to the holders of its two shares at Liquidation Date. The no-transaction value of each of ABC's two shares at Liquidation Date is thus $\$ 10$.

Equity /ssuance Scenario: Now suppose that $\mathrm{ABC}$ can conduct an equity issuance before Liquidation Date when the stock trades at $\$ 14$ (\$4 more than its actual value of $\$ 10$ ), selling a third share at that price. Assume that the $\$ 14$ received by $\mathrm{ABC}$ increases $\mathrm{ABC}$ 's Liquidation Date value from $\$ 20$ to $\$ 33$ because $\$ 1$ of social value is destroyed by the transaction. At Liquidation Date, the value of each of $\mathrm{ABC}$ 's three shares (including that held by CEO) is thus $\$ 11$.

It should be easy to see that the inflated-price issuance boosts CEO's payout while reducing social value. In the No-Transaction Scenario, ABC's social value is $\$ 20$. In the Equity Issuance Scenario, it is $\$ 19$ (\$33 distributed to shareholders at Liquidation Date less the $\$ 14$ raised from investors). ${ }^{93}$ But CEO's payout in the Equity Issuance Scenario is $\$ 1$ higher (\$11 rather than $\$ 10)$. The net effect of the inflated-price equity sale on social value and CEO's payoff can be summarized in Table 4 below:

Table 4. Rewards for Costly Expansion

\begin{tabular}{|l|l|l|}
\hline & Social Value & CEO Payoff \\
\hline No Equity Issuance & $\$ 20$ & $\$ 10$ \\
\hline Equity Issuance & $\$ 19$ & $\$ 11$ \\
\hline
\end{tabular}

As one can see, the inflated-price equity issuance rewards CEO even though social value is reduced. Thus, the equity given to CEO can incentivize her to direct the firm to sell shares even when the transaction destroys social value.

The problem is that tying an executive's payoff to the stock's future value aligns the executive's interests with those of nontrading shareholders but not with those of investing shareholders who buy additional stock from

92. I assume that $\mathrm{ABC}$ does not issue any dividends (or repurchase any equity) before Liquidation Date.

93. In the No-Transaction Scenario, all \$20 flows to shareholders at Liquidation Date. In the Equity Issuance Scenario, $\$ 14$ flows from shareholders during the equity issuance and $\$ 33$ flows back to shareholders at Liquidation Date (for a net amount of \$19). 
the firm. Thus, the executive has an incentive to take steps that transfer value from investing shareholders to nontrading shareholders even when such steps would destroy social value. And, as in the case of costly repurchases, this distortion arises even if the executive's payoff is tied to the stock's long-term value.

2. Do Other Pay Components Mitigate? -As we have seen, an executive whose payoff is tied to the stock's future value can be rewarded for engaging in value-wasting equity issuances when the stock is overpriced. However, equity comprises only part of an executive's compensation. The executive likely also receives a cash salary and bonus. In addition, the executive may hold stock that she can unload currently. Do these other forms of compensation mitigate the adverse incentives created by the equity held by the executive?

Unfortunately, none of these other components of the executive's pay package undermines executives' incentive to engage in costly expansion when the stock is overpriced. Indeed, given the well-known correlation between market capitalization and executive pay, salary and other forms of compensation may well rise if the executive expands the firm. ${ }^{94}$

What about any equity that the executive is free to unwind currently? The executive will have an incentive to sell the unwindable stock and still conduct an overpriced equity issuance to boost the value of her remaining shares. In fact, there is evidence that executives whose firms are selling overpriced stock simultaneously unload some of their own shares. ${ }^{95}$ In short, the incentive to engage in costly expansion is not weakened by other components of executives' pay packages.

\section{The Constant-Share Approach}

Parts II and III demonstrated that executives whose payoffs are tied to the future value of their firms' shares can be rewarded for engaging in both stock repurchases and equity issuances that reduce aggregate shareholder value - the amount of value flowing to all of the firm's shareholders over time. The problem is that the stock's future value does not reflect the value flowing to redeeming shareholders - those investors who sell shares back to the corporation - or the value flowing to investing shareholders - those investors who buy shares from the firm. Rather, the stock's future value reflects only the value flowing to one subset of shareholders-nontrading shareholders-investors who neither sell any of their stock to the firm nor buy any additional stock from the firm before that future date.

94. Lucian Bebchuk \& Yaniv Grinstein, Firm Expansion and CEO Pay 2-3 (Harvard John M. Olin Discussion Paper Series, Discussion Paper No. 533, 2007), available at http://papers.ssrn. com/abstract_id=838245.

95. See supra note 88 . 
In this Part, I explain how equity pay could be structured to reward executives for repurchases and equity issuances if and only if these transactions increase aggregate shareholder value. Subpart A puts forward and provides an overview of a "constant-share" approach to equity-based pay that would tie executives' payoffs to aggregate shareholder value- the value flowing to nontrading, redeeming, and investing shareholders in aggregateand thereby eliminate executives' incentives to engage in value-reducing repurchases and equity issuances merely to boost the stock's future value. Subpart B describes in more detail how the constant-share approach operates in the context of a repurchase. Subpart $\mathrm{C}$ describes how the approach operates in connection with an equity issuance.

My main goal in this Part is to explain the concept behind the constantshare approach rather than put forward a fully fleshed-out proposal for implementing it. Thus, in explaining the conceptual underpinnings of the constant-share approach, I make some simplifying assumptions. In particular, I assume an executive subject to the constant-share approach owns vested stock subject to a holding requirement (and no other equity in the firm), is risk-neutral, has sufficient liquidity to purchase additional shares, and cannot use hedging or other techniques to circumvent the constant-share arrangement. I also ignore tax considerations and the time value of money. A mathematical model of the constant-share approach can be found in the Appendix.

\section{A. Description of the Approach}

Under the constant-share approach, executives would be required to adjust their equity positions whenever the firm repurchases or issues shares such that executives' fractional ownership in the firm remains constant throughout the transaction. Thus, when the firm repurchases shares, an executive would be required to sell some of her shares to the firm. And when the firm issues shares, the executive would be required to buy additional shares.

Whether the firm buys or sells it own stock, the executive would transact with the firm on the same terms as the firm transacts with other investors. Thus, when the firm repurchases shares, the executive must sell shares to the firm at the repurchase price. Similarly, the executive must buy shares at the issue price when the firm sells shares.

For example, suppose than an executive (CEO) holds a certain fraction of the firm's equity at a particular point in time (say $2 \%$ ). If the firm repurchases $10 \%$ of its shares, CEO would be required to sell to the firm, at the same price the firm pays for the repurchased shares, $10 \%$ of her $2 \%$ block, or $0.2 \%$ of the firm's shares. Similarly, if the firm increases its outstanding shares by $10 \%$ in an equity offering, CEO would be required to buy, at the same price the firm receives for the newly issued stock, an amount equal to $10 \%$ of her $2 \%$ block, or $0.2 \%$ of the firm's outstanding 
shares. The effect of CEO's transactions would be to leave CEO with the same fraction of the firm's outstanding shares after the repurchase or share issuance as before-in this case, $2 \%{ }^{96}$

As I explain in more detail below, requiring an executive to participate in repurchases as a redeeming shareholder and in equity issuances as an investing shareholder in the same proportion as she owns stock in the company ensures that the executive's equity payoff is tied to the value flowing to all of the firm's shareholders, not just the value flowing to nontrading shareholders. Essentially, the constant-share approach would make the executive both a nontrading and redeeming shareholder in a repurchase and both a nontrading and investing shareholder in an equity issuance. Thus, the executive no longer financially benefits from repurchases and stock issuances that merely transfer wealth from one set of shareholders to another without generating any social value. Instead, the executive has an incentive to engage in repurchases and equity issuances if and only if they increase aggregate shareholder value.

The constant-share approach provides another benefit in addition to eliminating the incentive to engage in costly contractions and costly expansions. As Parts II and III explained, executives frequently manipulate the stock price around repurchases and equity issuances to further boost the value of their equity. Once executives have decided to conduct a repurchase, driving down the stock price before the repurchase increases the value of executives' equity to the extent they are indirect buyers of the repurchased stock. Similarly, given that an equity issuance will occur, driving up the stock price increases the value of executives' equity to the extent they are indirect sellers of the issued equity. The constant-share approach thus eliminates executives' equity-driven incentive to engage in such manipulations by ensuring that executives are neither indirect buyers nor indirect sellers in these transactions.

\section{B. Constant-Share Approach in a Repurchasing Firm}

When a firm repurchases shares, the constant-share approach ties an executive's equity payoff to the total amount of value flowing to both

96. Although I assume in the text that CEO sells and purchases shares whenever the firm transacts in its own stock, CEO's adjustments could be effected through the use of derivatives rather than the purchase or sale of actual shares. For example, if the firm issues 1,000,000 new shares, CEO could be required to swap, on the date her holding requirements terminate, (1) the value of 20,000 shares at the issuance price plus interest for (2) the value of 20,0000 shares on that date. Such a mechanism would avoid the need for the CEO to pay cash for additional shares.

Moreover, the adjustments required by the constant-share approach need not be made every time the firm transacts in its own stock. Rather, the firm could track its repurchases and equity offerings each year (and CEO's positions on the eve of each of these transactions) and, at year-end, require CEO to engage in a single transaction with the firm that leaves CEO in the same position as if contemporaneous adjustments had been made. The Appendix explains how an ex post adjustment could be effected. 
nontrading and redeeming shareholders. Thus, this mechanism eliminates the executive's incentive to engage in a repurchase merely because it transfers value from redeeming shareholders. Instead, the executive is rewarded for engaging in a repurchase if and only if the repurchase increases aggregate shareholder value.

To see why this is the case, suppose that an executive (CEO), at the time of a possible repurchase, owns $10 \%$ of the firm's stock. Suppose that the firm is considering purchasing $20 \%$ of the outstanding shares at the current trading price.

Absent the constant-share mechanism, CEO would own $12.5 \%$ of the firm's shares after the repurchase. ${ }^{97}$ Thus, CEO would receive $12.5 \%$ of the value flowing to nontrading shareholders - the shareholders who do not redeem their shares in the repurchase-and $0 \%$ of the value flowing to redeeming shareholders. CEO's equity payoff would thus reflect only the value flowing to nontrading shareholders rather than to all of the firm's shareholders affected by the transaction. As we saw in Part II, CEO may well be rewarded for engaging in a bargain-price repurchase even if it reduces aggregate shareholder value.

Under the constant-share approach, CEO would be required to participate in the $20 \%$ repurchase in an amount proportionate to her pretransaction ownership interest of the firm (10\%). Thus, shares sold by CEO to the firm would constitute $10 \%$ of the $20 \%$ block acquired by the firm (or $2 \%$ of the firm's outstanding stock). Put another way, because the firm is repurchasing $20 \%$ of all of its shares, CEO would be required to sell to the firm $20 \%$ of her $10 \%$ interest.

After the repurchase, CEO would continue to own $10 \%$ of the firm's equity. Thus, CEO would receive $10 \%$ of the value flowing to nontrading shareholders. But because CEO also held $10 \%$ of the equity repurchased by the firm, CEO would receive $10 \%$ of the value flowing to redeeming shareholders. As a result, CEO's payoff would equal $10 \%$ of the value flowing to all of the firm's shareholders affected by the transaction. Thus, CEO would have an incentive to conduct the repurchase if and only if the repurchase increases aggregate shareholder value.

\section{Constant-Share Approach in a Share-/ssuing Firm}

I now turn to consider how the constant-share approach operates when a firm issues equity. As I will show, the constant-share approach ties an executive's payoff to the total amount of value flowing to both nontrading and investing shareholders. Thus, the mechanism eliminates the executive's incentive to engage in an equity issuance merely because the issuance

97. Because the firm is repurchasing $20 \%$ of its stock, the proportional interest of each remaining shareholder, including CEO, will increase by $25 \%$. 
transfers value from investing shareholders. Instead, the executive will be rewarded for engaging in any equity issuance if and only if it increases aggregate shareholder value.

To see why this is the case, suppose that an executive (CEO), at the time of a possible equity issuance, owns $10 \%$ of the firm's stock. Suppose that the firm is considering issuing an amount of stock equal to $25 \%$ of the outstanding shares at the current trading price.

Absent a constant-share mechanism, CEO would own $8 \%$ of the firm's stock after the transaction. ${ }^{98}$ Thus, CEO would receive $8 \%$ of the value flowing to nontrading shareholders - the shareholders who do not invest in the equity issuance - and $0 \%$ of the value flowing to investing shareholders. CEO's equity payoff would thus reflect the value flowing to nontrading shareholders rather than to all of the firm's shareholders affected by the transaction. As we saw in Part III, CEO may well be rewarded for engaging in an inflated-price issuance even if it reduces aggregate shareholder value.

Under the constant-share approach, CEO would be required to buy $10 \%$ of the shares sold by the firm. Because the firm is selling an amount of shares equal to $25 \%$ of its pre-sale outstanding equity, CEO would be required to buy $2.5 \%$ of the firm's pre-sale equity in the equity issuance. That is, CEO would be required to increase her share ownership by $25 \%$, the proportion by which the equity offering increases the firm's outstanding shares.

After the equity issuance, CEO would continue to own $10 \%$ of the firm's equity. Thus, CEO would receive $10 \%$ of the value flowing to nontrading shareholders. But because CEO also buys $10 \%$ of the equity issued by the firm, CEO receives $10 \%$ of the value flowing to investing shareholders. As a result, CEO's payoff equals $10 \%$ of the value flowing to all of the firm's shareholders affected by the transaction. Thus, CEO would have an incentive to conduct the equity issuance if and only if the issuance increases aggregate shareholder value. ${ }^{99}$

\section{Conclusion}

Tying executive pay to the future value of a firm's stock is widely viewed as a useful means of incentivizing executives to generate value for shareholders. This Article has identified a potential cost to public investors of tying executive pay to the future value of a firm' stock, even the long-term value. In particular, tying executive pay to the stock's future value can

98. Because the firm is issuing an amount of equity equal to $25 \%$ of its pre-transaction outstanding shares, the proportional interest of each remaining shareholder, including CEO, will drop by $20 \%$.

99. I am assuming that CEO is risk-neutral. If CEO were risk-averse, she may be deterred from engaging in a value-increasing equity-financed expansion if she is required to buy enough equity to maintain her proportional ownership of the firm. It might thus be desirable to reduce the purchase requirement for a risk-averse executive. 
reward executives for engaging in share repurchases and equity issuances that reduce "aggregate shareholder value" - the amount of value flowing to all of a firm's shareholders over time.

The Article has also put forward a new "constant-share" approach to equity-based compensation that ties executives' equity payoffs to aggregate shareholder value. Under this approach, an executive would be required to sell some of her shares (or buy additional shares) whenever the firm repurchases its own stock (or issues new equity) so that the executive's proportional ownership in the firm remains constant as the firm transacts in its own stock. The Article showed that the constant-share approach would eliminate executives' incentives to engage in share repurchases and equity issuances that reduce aggregate shareholder value.

I hope that the analysis I have offered here will help sharpen understanding of the potentially negative effects of tying executive pay to the future value of a firm's stock-even its long-term value-and assist regulators, directors, and shareholders in improving executive compensation and corporate governance in public companies. 


\section{APPENDIX}

The Appendix provides an analytical framework for examining the effect of equity compensation and the constant-share approach on executives' incentives to engage in repurchases and equity issuances.

\section{Analytical Framework}

Consider a Corporation ( $\mathrm{ABC}$ ) that initially has a single share outstanding and exists in three sequential periods: Time $\mathrm{T}=0$, Time $\mathrm{T}=1$, and Time $\mathrm{T}=2$.

- At $\mathrm{T}=0, \mathrm{ABC}$ has a single risk-neutral manager (CEO) who is granted a fraction $\pi$ of $A B C$ 's equity that she must hold until $T=2$. In analyzing CEO's incentives, I assume CEO seeks solely to maximize the value of her equity.

- At $\mathrm{T}=1, \mathrm{ABC}$ 's equity trades for a price $\mathrm{P}_{1}$ per share and $\mathrm{ABC}$ may or may not repurchase or issue an additional amount of equity equal to a fraction $\alpha$ of its single share.

- At $\mathrm{T}=2, \mathrm{ABC}$ is liquidated and its value is distributed pro rata to its shareholders.

$A B C$ 's $T=2$ value will depend on whether there has been a transaction in $A B C$ 's stock at $T=1$. In the absence of any transactions in the firm's stock (such as a repurchase or sale of equity), $\mathrm{ABC}$ 's $\mathrm{T}=2$ value is $\mathrm{V}$.

If there is a repurchase (or sale) of equity, $A B C$ 's $T=2$ value will be reduced (increased) by the amount paid (received) for any stock repurchased (sold) at $\mathrm{T}=1$ plus an amount $\mathrm{X}$ representing the efficiency effects of the transaction on $A B C$ 's value. From an economic perspective, $A B C$ should repurchase equity or issue equity if and only if (iff) $\mathrm{X}>0$. 
Figure 1. Sequence of Events for $A B C$ Corporation

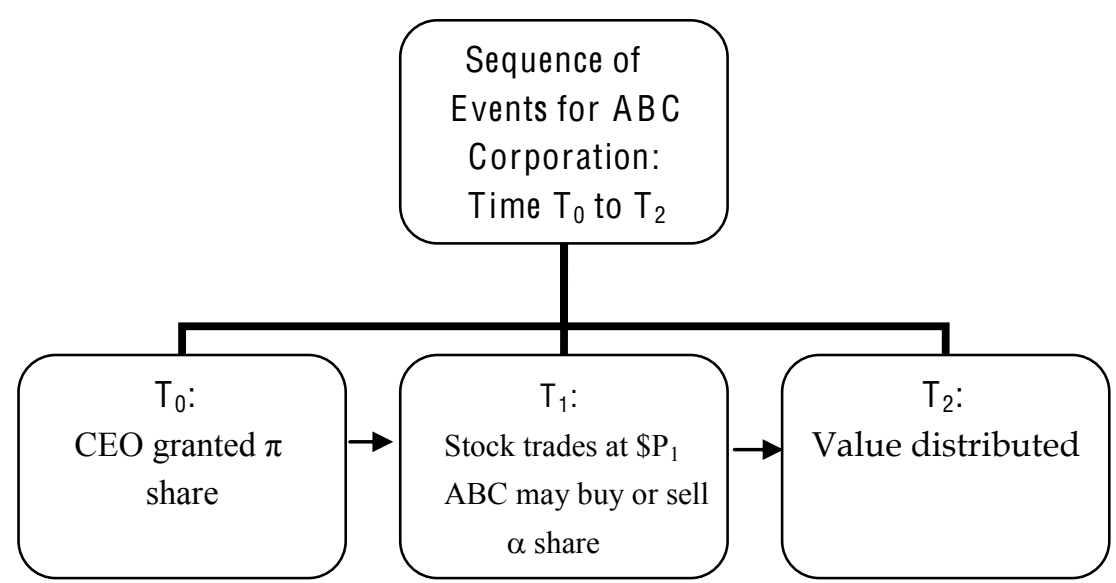

Social Value and Final-Period Stock Value. Social value (SV) is the net amount of value flowing from $\mathrm{ABC}$ to its shareholders between $\mathrm{T}=0$ and $\mathrm{T}=2$. The final-period stock value is $\mathrm{ABC}$ 's $\mathrm{T}=2$ value, divided by the number of shares outstanding at $\mathrm{T}=2$.

No-Transaction Scenario. Denote $\mathrm{SV}_{\mathrm{n}}$ as $\mathrm{ABC}$ 's social value when $\mathrm{ABC}$ neither repurchases nor issues equity at $\mathrm{T}=1$. Because the only value flowing to shareholders is $A B C$ 's $T=2$ value $V$,

(1a) $\mathrm{SV}_{\mathrm{n}}=\mathrm{V}$.

Denote $\mathrm{P}_{2 \mathrm{n}}$ as the final-period stock value if there is no repurchase or equity issuance. Because $A B C$ 's $T=2$ value is $V$ and there is one share outstanding at $\mathrm{T}=2$,

(2a) $P_{2 n}=V$.

Repurchase Scenario. Denote $\mathrm{SV}_{\mathrm{r}}$ as $\mathrm{ABC}$ 's social value when $\mathrm{ABC}$ repurchases $\alpha$ share at $T=1$ for a price $P_{1}$, where the repurchase changes $A B C$ 's $T=2$ value by $X$. Because $A B C$ distributes $\alpha \mathrm{P}_{1}$ to shareholders at $\mathrm{T}=1$ and $\left(\mathrm{V}-\alpha \mathrm{P}_{1}+\mathrm{X}\right)$ at $\mathrm{T}=2$,

(1b) $\mathrm{SV}_{\mathrm{r}}=\alpha \mathrm{P}_{1}+\left(\mathrm{V}-\alpha \mathrm{P}_{1}+\mathrm{X}\right)=\mathrm{V}+\mathrm{X}$.

Denote $\mathrm{P}_{2 \mathrm{r}}$ as the final-period stock value if there is a repurchase. Because $A B C$ 's $T=2$ value is $\left(\mathrm{V}-\alpha \mathrm{P}_{1}+\mathrm{X}\right)$ and there is $(1-\alpha)$ share outstanding at $\mathrm{T}=2$, 
(2b) $\mathrm{P}_{2 \mathrm{r}}=\left(\mathrm{V}-\alpha \mathrm{P}_{1}+\mathrm{X}\right) /(1-\alpha)$.

Equity-/ssuance Scenario. Denote $\mathrm{SV}_{\mathrm{i}}$ as $\mathrm{ABC}$ 's social value when $A B C$ issues $\alpha$ share at $T=1$ for a price $\mathrm{P}_{1}$, where the issuance changes $A B C$ 's $\mathrm{T}=2$ value by $\mathrm{X}$. Because $\mathrm{ABC}$ takes in $\alpha \mathrm{P}_{1}$ from shareholders at $\mathrm{T}=1$ and distributes $\left(\mathrm{V}+\alpha \mathrm{P}_{1}+\mathrm{X}\right)$ at $\mathrm{T}=2$,

$$
\text { (1c) } \mathrm{SV}_{\mathrm{i}}=\left(\mathrm{V}+\alpha \mathrm{P}_{1}+\mathrm{X}\right)-\alpha \mathrm{P}_{1}=(\mathrm{V}+\mathrm{X}) \text {. }
$$

Denote $\mathrm{P}_{2 \mathrm{i}}$ as the final-period stock value if there is an equity issuance. Because $A B C$ 's $T=2$ value is $\left(\mathrm{V}+\alpha \mathrm{P}_{1}+\mathrm{X}\right)$ and there is $(1+\alpha)$ share outstanding at $\mathrm{T}=2$,

(2c) $\mathrm{P}_{2 \mathrm{i}}=\left(\mathrm{V}+\alpha \mathrm{P}_{1}+\mathrm{X}\right) /(1+\alpha)$.

SV and the final-period stock value for each scenario are summarized in the table below.

Table 5. Social Value and Stock Value

\begin{tabular}{|l|l|l|}
\hline & Social Value & Stock Value \\
\hline No transaction & $\mathrm{V}$ & $\mathrm{V}$ \\
\hline Repurchase & $\mathrm{V}+\mathrm{X}$ & $\left(\mathrm{V}-\alpha \mathrm{P}_{1}+\mathrm{X}\right) /(1-\alpha)$ \\
\hline Equity issuance & $\mathrm{V}+\mathrm{X}$ & $\left(\mathrm{V}+\alpha \mathrm{P}_{1}+\mathrm{X}\right) /(1+\alpha)$ \\
\hline
\end{tabular}

\section{CEO's Incentive to Engage in Costly Contraction}

Consider CEO's incentive to repurchase at $\mathrm{T}=1$ when her payoff is tied to the $\mathrm{T}=2$ stock value. Given CEO's incentive to maximize the $\mathrm{T}=2$ stock value, it follows from (2a) and ( $2 \mathrm{~b})$ that $\mathrm{CEO}$ will repurchase at $\mathrm{T}=1$ iff

(3) $\left(\mathrm{V}-\alpha \mathrm{P}_{1}+\mathrm{X}\right) /(1-\alpha)>\mathrm{V}$.

Simplifying (3) yields

(4) $\mathrm{V}-\mathrm{P}_{1}>-\mathrm{X} / \alpha$.

It follows from (4) that CEO has an incentive to engage in a costly (value-reducing) repurchase when

(5) $0>\mathrm{X}>\alpha\left(\mathrm{P}_{1}-\mathrm{V}\right)$. 
Remark: If $\mathrm{P}_{1} \geq \mathrm{V}$ (the stock is either properly priced or overpriced at $\mathrm{T}=1$ ), CEO does not have an incentive to conduct a costly repurchase. However, if $\mathrm{P}_{1}<\mathrm{V}$ (the stock is underpriced at $\mathrm{T}=1$ ), CEO may have an interest in conducting a costly repurchase.

\section{CEO's Incentive to Engage in Costly Expansion}

Now consider CEO's incentive to issue equity at $\mathrm{T}=1$ when her payoff is tied to the $\mathrm{T}=2$ stock value. Given CEO's incentive to maximize the $\mathrm{T}=2$ stock value, it follows from (2a) and (2c) that $\mathrm{CEO}$ will issue equity at $\mathrm{T}=1$ iff

(6) $\left(\mathrm{V}+\alpha \mathrm{P}_{1}+\mathrm{X}\right) /(1+\alpha)>\mathrm{V}$.

Simplifying (6) yields

(7) $\mathrm{P}_{1}-\mathrm{V}>-\mathrm{X} / \alpha$.

It follows from (7) that $\mathrm{CEO}$ has an incentive to engage in a costly (value-wasting) equity issuance when

(8) $0>\mathrm{X}>\alpha\left(\mathrm{V}-\mathrm{P}_{1}\right)$.

Remark: If $\mathrm{P}_{1} \leq \mathrm{V}$ (the stock is either properly priced or underpriced at $\mathrm{T}=1$ ), CEO does not have an incentive to engage in costly expansion. However, if $\mathrm{P}_{1}>\mathrm{V}$ (the stock is overpriced at $\mathrm{T}=1$ ), CEO may benefit from engaging in costly expansion.

\section{Constant-Share Approach}

Under the constant-share approach, CEO must participate in a repurchase (issuance) by selling (buying) a fraction of the shares purchased (sold) by the company equal to her pre-transaction percentage interest in $\mathrm{ABC}, \pi$.

Denote CEO's $\mathrm{T}=2$ payoff if there is no repurchase as $\mathrm{W}_{\mathrm{n}}$, if there is a repurchase as $\mathrm{W}_{\mathrm{r}}$, and if there is a stock issuance as $\mathrm{W}_{\mathrm{i}}$.

If there is no repurchase or equity issuance, the $\mathrm{T}=2$ stock value is $\mathrm{V}$ CEO owns $\pi$ share. It follows that 
(9a) $\mathrm{W}_{\mathrm{n}}=\pi \mathrm{V}$.

If there is a repurchase of $\alpha$ share at $\mathrm{T}=1$ for price $\mathrm{P}_{1}, \mathrm{CEO}$ will be required to sell $\pi \alpha$ share at price $\mathrm{P}_{1}$ to $\mathrm{ABC}$. CEO thus receives $\pi \alpha \mathrm{P}_{1}$ at $\mathrm{T}=1$ and is left with $\pi(1-\alpha)$ share at $T=2$. It follows from this and (2a) that

(9b) $\mathrm{W}_{\mathrm{r}}=\pi \alpha \mathrm{P}_{1}+\pi(1-\alpha)\left(\mathrm{V}-\alpha \mathrm{P}_{1}+\mathrm{X}\right) /(1-\alpha)=\pi(\mathrm{V}+\mathrm{X})$.

If there is an issuance of equity at $\mathrm{T}=1$, CEO will pay $\pi \alpha \mathrm{P}_{1}$ for additional equity and own $\pi(1+\alpha)$ share at $\mathrm{T}=2$. It follows from this and (2c) that

$$
\text { (9c) } \mathrm{W}_{\mathrm{i}}=-\pi \alpha \mathrm{P}_{1}+\pi(1+\alpha)\left(\mathrm{V}+\alpha \mathrm{P}_{1}+\mathrm{X}\right) /(1+\alpha)=\pi(\mathrm{V}+\mathrm{X}) .
$$

CEO's payoff under each scenario can be summarized in the following table.

Table 6: Social Value and CEO Payoff Under the Constant-Share Approach

\begin{tabular}{|l|l|l|}
\hline & Social Value & CEO Payoff \\
\hline No transaction & $\mathrm{V}$ & $\pi \mathrm{V}$ \\
\hline Repurchase & $\mathrm{V}+\mathrm{X}$ & $\pi(\mathrm{V}+\mathrm{X})$ \\
\hline Equity issuance & $\mathrm{V}+\mathrm{X}$ & $\pi(\mathrm{V}+\mathrm{X})$ \\
\hline
\end{tabular}

Thus, CEO has an incentive to undertake a repurchase or equity issuance iff $X>0$. That is, CEO would undertake the transaction if and only if it increases ABC's social value.

\section{Ex Post Implementation}

Until now it has been assumed that CEO participates pro rata in any equity transaction at $\mathrm{T}=1$. Thus, because $\mathrm{CEO}$ owns $\pi$ share of $\mathrm{ABC}$ 's equity, she would sell or buy $\pi \alpha$ share when ABC buys or sells $\alpha$ share. Under this constant-share approach, CEO's payoff would be tied to ABC's social value.

However, CEO's payoff could also be tied to ABC's social value through the use of an ex post adjustment made to CEO's position after the equity transaction takes place. Denote as $\beta \pi$ the amount of shares CEO must sell (or buy) after ABC's repurchase (or equity offering) in order to tie CEO's payoff to ABC's social value. Such an ex post adjustment would 
change the amount of equity outstanding at $\mathrm{T}=2$ and $\mathrm{ABC}$ 's $\mathrm{T}=2$ value. (For simplicity, I assume that the ex post adjustment itself has no efficiency effect and therefore no effect on $\mathrm{ABC}$ 's social value.)

Suppose $A B C$ repurchases $\alpha$ share at $T=1$ for price $P_{1}$, and then (between $\mathrm{T}=1$ and $\mathrm{T}=2$ ) $\mathrm{CEO}$ sells $\beta \pi$ share for price $\mathrm{P}_{1}$.

Denote CEO's payoff in a repurchase when there is an ex post adjustment as $\mathrm{W}_{\mathrm{r}}$. Because $\mathrm{ABC}$ 's value at $\mathrm{T}=2$ will be $\mathrm{V}-[\alpha+\beta \pi] \mathrm{P}_{1}+\mathrm{X}$, and $\mathrm{ABC}$ will have $1-\alpha-\beta \pi$ share outstanding, it follows that

(10) $\mathrm{W}_{\mathrm{r}}{ }^{\prime}=\beta \pi \mathrm{P}_{1}+\pi\left(\mathrm{V}-[\alpha+\beta \pi] \mathrm{P}_{1}+\mathrm{X}\right) /(1-\alpha-\beta \pi)$.

Aligning CEO's payoff with $A B C$ 's social value requires that $\mathrm{W}_{\mathrm{r}}{ }^{\prime}=\mathrm{W}_{\mathrm{r}}$, which in turn implies that

(11) $\mathrm{W}_{\mathrm{r}}^{\prime}=\pi(\mathrm{V}+\mathrm{X})$.

From (10) and (11), it follows that

(12) $\beta=\alpha /(1-\pi)$.

Thus, after ABC's repurchase of $\alpha$ share at $\mathrm{T}=1$, requiring CEO to sell $\mathrm{ABC} \alpha /(1-\pi)$ share will ensure CEO's proportional ownership remains unchanged.It can easily be shown that the post-transaction adjustment in the case of an equity issuance is identical: CEO must buy $\beta \pi$ share at $P_{1}$, where $\beta$ $=\alpha /(1-\pi)$. 